Announcements

\title{
NATIONAL CENTRE FOR ANTARCTIC \& OCEAN RESEARCH
}

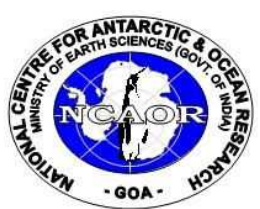

Ministry of Earth Sciences, Government of India

Headland Sada, Goa 403804

Phone: (0832)-2525 600; fax: (0832)-252 0877

http://www.ncaor.gov.in

\section{CALL FOR PROPOSALS FOR SCIENTIFIC RESEARCH IN THE ARCTIC REGION}

The National Centre for Antarctic and Ocean Research (NCAOR), an autonomous R \& D Institution under the Ministry of Earth Sciences (MoES), Government of India has been designated as the nodal agency responsible for the planning, co-ordination and implementation of India's scientific research endeavours in the Arctic realm. On behalf of the Ministry, NCAOR invites research proposals from national scientific organisations/institutions, research laboratories and universities with a sustained interest in polar research for funded access (comprising travel, DA as per the Government of India norms, polar clothing, boarding and lodging) to the Ny-Ålesund Research Infrastructure in Svalbard, Norway.

Scientific research proposals are invited, specifically within the following fields of Arctic research:

- Atmospheric Science with special reference to study of aerosols over the Arctic

- Marine Science: physical, chemical, geological and microbiological studies in the Kongsfjorden

- Environmental Chemistry: Natural contaminants in food webs and long range pollutants

- Cryospheric studies: Snow and ice chemistry, glaciology

In addition, the applicants are also encouraged to visit websites www.ssf.npolar.no and www.kingsbay.no for more information regarding Arctic research. Application Deadline: 23 January 2012.

Complete programme, eligibility, and application information is available at: http://www.ncaor.nic.in/

Advt. No: NCAOR/65/11

Director

Email: rasik@ncaor.org

\section{NATIONAL SEMINAR ON RECENT ADVANCES AND FUTURE CHALLENGES IN GEOCHEMISTRY AND GEOPHYSICS: THE INDIAN SCENARIO}

AND

\section{ANNUAL GENERAL BODY MEETING OF THE INDIAN SOCIETY OF APPLIED GEOCHEMISTS - 2012}

The above seminar is being organised by the Department of Geology, Banaras Hindu University and the Indian Society of Applied Geochemists (ISAG) during 22-24 February 2012. For further details, please contact: Dr. N.V. Chalapathi Rao, Department of Geology, Centre of Advanced Study, Banaras Hindu University, Varanasi - 221005. Cell \#: 09935647365; Email: isagbhu2012@gmail.com

"Printed by M. Nagaraju and Published by R.H. Sawkar on behalf of the Geological Society of India, No.63, 12 ${ }^{\text {th }}$ Cross, Basappa Layout, Gavipuram P.O., P.B. No.1922, Bangalore - 560019 and Printed at M/s Driti Enterprises, No.117/19. Cauverynagar Main Road, B.S.K. $3^{\text {rd }}$ Stage, Bangalore - 560085 and Published at the Geological Society of India, No.63, $12^{\text {th }}$ Cross, Basappa Layout, Gavipuram P.O., P.B. No.1922, Bangalore - 560 019” - Editor: B. Mahabaleswar. 